\title{
PENGARUH PEMBERIAN SENAM KEGEL UNTUK MENURUNKAN DERAJAT INKONTINENSIA URIN PADA LANSIA
}

\author{
Nova Relida Samosir, SST.FT., M.Fis ${ }^{1)}$ Yulia Tetra Ilona ${ }^{2)}$ \\ ${ }^{1,2)}$ Program Studi D-III Fisioterapi Fakultas Kedokteran dan Ilmu Kesehatan \\ Universitas Abdurrab \\ J1. Riau Ujung no. 73 Pekanbaru \\ email : nova.relida@univrab.ac.id
}

\begin{abstract}
Background. Urinary incontinence by the international continents society (ICS) defines it as a condition in which uncontrolled urine output is a social or hygienic problem in the elderly and can be proven objectively. Purpose. This study aimed at patients with urinary incontinence to improve pelvic floor muscles. Physiotherapy interventions that can be given to patients with urinary incontinence in dealing with decreased function in the pelvic floor muscles can be done with a variety of actions including the administration of Kegel exercises. Research methods. The research conducted is a case study with a pre and post test research design. Results. The results of the study in sample I obtained changes in improvement in pelvic floor muscle described by changes in the scale of RUIS at TO score value of 15 and at score T12 obtained score 10. In sample II obtained changes in improvement at TO score value 13 and at T12 score obtained 10. Then in the sample III obtained changes in improvement. At TO the score of 15 and at T12 obtained a score of 9.
\end{abstract}

Keywords: Urinary incontinence, Kegel exercises, Case Study

\begin{abstract}
Abstrak
Latar Belakang. Inkontinensia urin oleh international continence society (ICS) mendefinisikan sebagai suatu kondisi dimana keluarnya urin yang tidak dapat dikendalikan yang menjadi masalah sosial atau hegienis pada lansia dan dapat dibuktikan secara objektif. Tujuan. Penelitian ini ditujukan kepada pasien kondisi inkontinensia urin untuk meningkatkan otot dasar panggul. Intervensi fisioterapi yang dapat diberikan pada penderita inkontinensia urin dalam mengatasi penurunan fungsi pada otot dasar panggul dapat dilakukan dengan berbagai tindakan diantaranya dengan pemberian teknik senam kegel. Metode Penelitian. Penelitian yang dilakukan merupakan case study dengan desain penelitian pre and post test. Hasil. Hasil penelitian pada sampel I didapat perubahan perbaikan peningkatan otot dasar panggul digambarkan dengan perubahan skala RUIS pada $T_{0}$ nilai skor 15 dan pada $T_{12}$ didapatkan skor 10. Pada sampel II didapat perubahan perbaikan pada $T_{0}$ nilai skor 13 dan pada $T_{12}$ didapatkan skor 10. Kemudian pada sampel III didapat perubahan perbaikan. Pada $T_{0}$ nilai skor 15 dan pada $T_{12}$ didapatkan skor 9.
\end{abstract}

Kata kunci: Inkontinensia Urin, Senam Kegel, studi kasus 


\section{Pendahuluan}

Proses menua (aging proses) biasanya akan ditandai dengan adanya perubahan fisik-biologis, mental ataupun psikososial. Perubahan fisiologis diantaranya adalah, penurunan sistem persyarafan, sistem pendengaran, sistem penglihatan, sistem kardiovaskuler, sistem pengaturan temperatur tubuh, sistem respirasi, sistem endokrin, sistem kulit, sistem perkemihan, sistem musculokeletal, Perubahan mental pada lansia yaitu terjadi perubahan kepribadian, memori dan perubahan intelegensi, perubahan psikososial adalah perubahan dalam cara hidup ${ }^{(1)}$.

Perubahan pada sistem perkemihan lansia terjadi pada ginjal, di mana ginjal mengalami pengecilan dan nefron menjadi atrofi. Aliran ginjal menurun hingga $50 \%$, fungsi tubulus berkurang mengakibatkan blood urea nitrogen (BUN) meningkat hingga $21 \mathrm{mg} \%$, berat jenis urin menurun, serta nilai ambang ginjal terhadap glukosa meningkat. Pada kandung kemih, otot-otot melemah, sehingga kapasitanya menurun hingga $200 \mathrm{ml}$ yang menyebabkan frekuensi berkemih meningkat. Pada laki-laki, pembesaran kelenjar prostat menyebabkan obstruksi aliran urin dari kandung kemih ${ }^{(2)}$.

Inkontinensia urin adalah salah satu masalah yang banyak dialami oleh lansia dan perlu mendapatkan perhatian seiring dengan meningkatnya populasi lanjut usia. Inkontinensia urin adalah pengeluaran urin tanpa disadari (involunter), dalam jumlah dan frekuensi yang cukup sehingga mengakibatkan masalah gangguan kesehatan atau sosial, hegienis, psikososial, dan ekonomi $^{(3)}$.

Prevalensi kelainan ini cukup tinggi, yakni pada wanita lebih kurang 10-40\% dan 4-8\% sudah dalam keadaan cukup parah pada saat datang berobat. Pada pria, prevalensinya lebih rendah dari pada wanita, yaitu separuhnya. Survey yang dilakukan di berbagai negara Asia didapatkan bahwa prevalensi pada beberapa bangsa Asia adalah $12,2 \%$ (14,8\% pada wanita dan $6,8 \%$ pada pria). Pada lanjut usia prevalensinya lebih tinggi dari pada usia reproduksi. Diokno et al. melaporkan prevalensi inkontinensia urine pada wanita lansia sebesar $38 \%$ dan pada pria $19 \%{ }^{(4)}$.

\section{Tinjauan Pustaka}

\subsection{Kelemahan Otot Dasar Panggul Pada Lansia}

Seiring dengan bertambahnya usia mengakibatkan terjadinya perubahan anatomi dan fungsi organ kemih lansia, obesitas, menopause, penambahan berat dan tekanan selama hamil dapat menyebakan melemahnya otot dasar panggul karena ditekan selama sembilan bulan, besarnya peningkatan tekanan intra abdomen mampu untuk menekan urin ke uretra dengan sangat mudah. Proses persalinan yang lebih dari satu kali mengakibatkan timbulnya penguluran otot dasar panggul dan saraf pudendal sehingga timbulnya kelemahan pada otot dasar panggul dan tindakantindakan yang berkenaan dengan persalinan tersebut juga dapat membuat otot-otot dasar panggul rusak akibat regangan otot dan jaringan penunjang serta robekan jalan lahir ${ }^{(5)}$.

Secara umum penyebab inkontinensia urin adalah kelainan urologis, neurologis atau fungsional. Kelainan urologis pada inkontinensia urin dapat disebabkan karena adanya radang, batu, tumor dan divertikel. Kelainan neurologis, seperti pada pasien stroke, trauma pada medulla spinalis, demensia dan lain-lain. Inkontinensia urin pada wanita dapat terjadi akibat melemahnya otot dasar panggul yang dapat disebabkan karena usia lanjut, menopause, kehamilan, pasca melahirkan, kegemukan (obesitas), kurang aktivitas atau adanya infeksi saluran kemih. Dengan menurunnya kadar hormon estrogen pada wanita lanjut usia, akan terjadi penurunan tonus otot vagina dan otot pintu saluran kemih (uretra), sehingga menyebabkan terjadinya inkontinensia urin ${ }^{(6)}$.

Mekanisme terjadinya inkontinensia urin adalah hasil yang kompleks dan berkoordinasi antara elemen kontinensia sentral dan perifer. Pada wanita ikontinensia urin selama stress (peningkatan tekanan intra abdomen) di pertahankan oleh beberapa mekanisme. Pertama transmisi pasif tekanan abdominan ke uretra proksimal. Refleks penahanan yang melibatkan kontraksi aktif dari otot lurik dan sfingter uretra eksternus dapat mencegah sementara inkontinensia. Bagaimana tekanan abdominan yang ditransmiter ke uretra proksimal bukan merupakan faktor utama dalam meningkatkan tekanan uretra. Tekanan abdominan yang di transmisikan ke proksimal uretra menuju bagian anterior kemudian menuju ke bagian posterior. Selama proses pengosongan ligamen pubo uretra dan jaringan ikat vagina ke otot pelvis dan fascia secara aktif merubah posisi leher kandung kemih dan uretra proksimal. Bagian ini mengandung kedua fascia dan otot polos. Perubahan posisi ini akan menekan uretra melawan pubis selama terisinya dan peregangan kandung kemih. Jadi inkontinensia urine merupakan hasil dari kombinasi kerjasama anatomi secara pasif dan kontraksi otot yang aktif.

Inkontinensia urin stres merupakan jenis inkontinensia urin yang paling banyak dijumpai pada wanita lanjut usia. Inkontinensia urin stres adalah keluarnya urin tanpa disadari pada saat aktifitas atau saat bersin atau batuk. Faktor yang terlibat di dalam inkontinensia urin dibagi menjadi mekanisme kontrol sentral dan perifer. Mekanisme kontrol sentral termasuk iput dari korteks serebri, mid brain, thorak spinal, sacral spinal yang terus ke otonom dan persarafan somatik menuju ke organ 
(kandung kemih, uretra), otot dan struktur tulang peyangganya $^{(7)}$.

\subsection{Metode dan Teknik Intervensi \\ 2.2.1 Senam Kegel}

Peran fisioterapi pada kondisi inkontinensia urin adalah senam kegel, yaitu senam yang berupa latihan untuk menguatkan otot panggul atau senam yang bertujuan untuk memperkuat otot - otot dasar panggul terutama otot pubococcygeal sehingga seorang wanita dapat memperkuat otot - otot saluran kemih. Senam kegel juga dapat menyembuhkan ketidakmampuan menahan BAK (inkontinensia urin). Kurangnya latihan pada otototot detrusor di kandung kemih menyebabkan kemampuan kandung kemih untuk mengembang berkurang sehingga kapasitas dalam kandung kemih menjadi menurun dan menyebabkan kandung kemih cepat penuh. Terapi ini diberikan jika pasien dapat memiliki fungsi kognitif yang baik, keberhasilan terletak pada keinginan dan kedisiplinan pasien dan beri motivasi untuk melakukan latihan. Senam kegel dapat dilakukan ketika menonton tv dan berbaring dan bisa dijadikan kebiasaan positif kapanpun juga.

\section{a. Teknik Pelaksanaan}

Teknik senam kegel yang paling sederhana dan mudah dilakukan adalah dengan seolah-olah menahan buang air kecil (BAK) atau kontraksikan otot seperti menahan BAK pertahankan selama 6 detik, kemudian relaksasikan. Ulangi latihan sebanyak lima kali berturut-turut. Secara bertahap tingkatkan lamanya menahan BAK 15-20 detik, lakukan secara serial setidaknya 6-12 kali tiap latihan ${ }^{(8)}$.

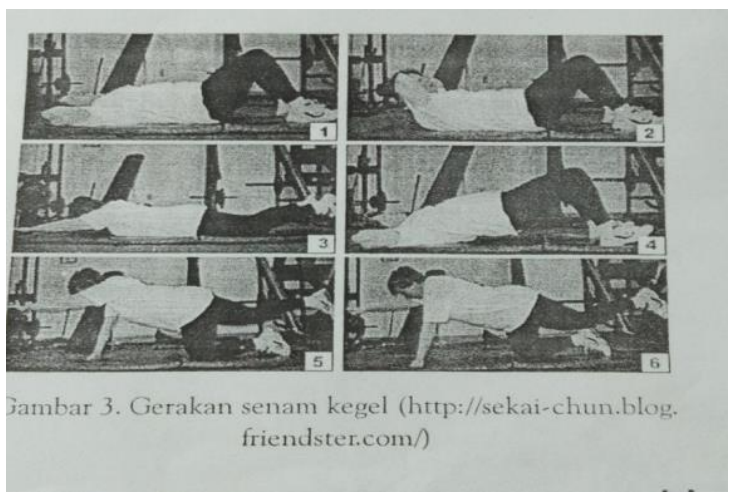

Gambar 2.5 Senam Kegel

Sumber : Widianti, 2018

\section{b. Mekanisme Peningkatan Kekuatan Otot Dasar Panggul pada senam Kegel}

Senam kegel adalah latihan yang bertujuan untuk memperkuat sfingter kandung kemih dan otot dasar panggul, yaitu otot-otot yang berperan mengatur miksi dan gerakan yang mengencangkan, melemaskan kelompok otot panggul dan daerah genital, terutama otot pubococcygeal, sehingga seorang wanita dapat memperkuat otot-otot saluran kemih $^{(9)}$.

Mekanisme kontraksi dan meningkatkan tonus otot polos dinding kandung kemih dapat terjadi karena adanya rangsang pada otot polos kandung kemih sebagai dampak dari latihan. Latihan ini dapat menimbulkan rangsangan sehingga meningkatkan aktivasi dari kimiawi, neuromuskuler dan muskuler. Otot polos kandung kemih mengandung filamen aktin dan miosin yang mempunyai sifat kimiawi dan saling berinteraksi. Proses interaksi diaktifkan oleh ion kalsium dan adenotriposfat (ATP) selanjutnya dipecah menjadi adenodifosfat (AD) untuk memberikan energi bagi konstraksi muskulus detrussor kandung kemih. Rangsangan melalui neuromuskuler akan meningkatkan rangsangan pada serat saraf otot polos kandung kemih terutama saraf parasimpatik yang merangsang produksi asetil cholin sehingga mengakibatkan terjadinya kontraksi. Mekanisme melalui muskulus, terutama otot polos kandung kemih akan meningkatkan metabolisme mitokondria untuk menghasilkan ATP yang dimanfaatkan oleh otot polos kandung kemih sebagai energi untuk kontraksi dan meningkatkan tonus otot polos kandung kemih. Frekwensi latihan sangat bergantung dari jenis latihan yang diberikan dan optimalisasi sangat ditentukan oleh benar atau tidaknya gerakan yang dilakukan. Latihan dilakukan sampai klien mencapai konrol berkemih (10).

\subsection{Pemeriksaan dan Pengukuran}

Penurunan kekuatan otot dasar panggul yang dapat menyebabkan inkontinensia urin pada lansia dapat di lakukan dengan bermacam-macam alat ukur salah satunya skala RUIS (Revised Urinary Incontinence Scale) adalah skala lima item yang singkat dan akurat yang dapat digunakan untuk menilai inkontinensia urin dan memantau hasil pasien setelah terapi. Total skor RUIS kemudian dihitung dengan menjumlahkan nilai seseorang untuk setiap pertanyaan dengan total skor 0-16, dari jumlah yang di dapat maka akan tahu seberapa tingkat keparahan inkontinensia urin, semakin parah inkontinensia maka otot dasar panggul semakin lemah dan semakin ringan inkontinensia maka semakin kuat pula otot dasar panggul. 
Tabel 2.3 Skala Ruis

\begin{tabular}{|c|c|c|c|c|c|}
\hline \multicolumn{6}{|c|}{ Skala Ruis } \\
\hline \multirow[b]{2}{*}{$\begin{array}{l}\mathbf{N} \\
\mathbf{0}\end{array}$} & \multirow[b]{2}{*}{ Pertanyaan } & \multicolumn{4}{|c|}{ Skor } \\
\hline & & $\begin{array}{c}\text { Tidak } \\
\text { Ada } \\
\text { (0) }\end{array}$ & $\begin{array}{c}\text { Jaran } \\
\text { g } \\
(\mathbf{1})\end{array}$ & $\begin{array}{c}\text { Terkad } \\
\text { ang } \\
(2)\end{array}$ & $\begin{array}{c}\text { Seri } \\
\text { ng } \\
(3)\end{array}$ \\
\hline 1. & $\begin{array}{l}\text { Apakah } \\
\text { kebocoran } \\
\text { atau rembesan } \\
\text { sudah keluar } \\
\text { pada saat } \\
\text { terasa kemih? }\end{array}$ & & & & \\
\hline 2. & $\begin{array}{l}\text { Apakah } \\
\text { kebocoran } \\
\text { atau rembesan } \\
\text { sudah keluar } \\
\text { saat ada } \\
\text { aktivitas, } \\
\text { batuk atau } \\
\text { bersin? }\end{array}$ & & & & \\
\hline 3. & $\begin{array}{l}\text { Seberapa } \\
\text { banyak } \\
\text { kebocoran } \\
\text { urin (menetes) } \\
?\end{array}$ & & & & \\
\hline 4. & $\begin{array}{l}\text { Seberapa } \\
\text { sering } \\
\text { kebocoran } \\
\text { urin } \\
\text { merembes? }\end{array}$ & $\begin{array}{l}0=\text { tidak } \\
\text { ada } \\
1= \\
\text { kurang } \\
\text { dari } \\
\text { sebulan } \\
\text { sekali } \\
2- \\
\text { beberapa } \\
\text { kali } \\
\text { sebulan } \\
3= \\
\text { beberapa } \\
\text { kali } \\
\text { seminggu } \\
4=\text { setiap } \\
\text { hari/setia } \\
\text { p malam }\end{array}$ & & & \\
\hline 5. & $\begin{array}{l}\text { Seberapa } \\
\text { banyak } \\
\text { kebocoran } \\
\text { urin yang } \\
\text { merembes? }\end{array}$ & $\begin{array}{l}0=\text { tidak } \\
\text { ada } \\
1= \\
\text { tetesan } \\
2= \\
\text { percikan } \\
\text { kecil } \\
3= \\
\text { banyak } \\
\text { (lebih) }\end{array}$ & & & \\
\hline
\end{tabular}

Sumber: Sansoni et al, 2011

Keterangan :

$\begin{array}{lll}0-3 & =\begin{array}{l}\text { tidak ada inkontinensia urin } \\ \text { (normal) }\end{array} \\ 4-8 & =\text { inkontinensia urin ringan } \\ 9-12 & =\text { inkontinensia urin sedang } \\ 13-16 & =\text { inkontinensia urin berat }\end{array}$

\section{Metode Penelitian}

\subsection{Rancangan Penelitian}

Jenis penelitian yang digunakan adalah penelitian case study dengan desain penelitian pre and post test yaitu membandingkan antara skor sebelum dan sesudah intervensi senam kegel.

\subsection{Tempat dan Waktu}

Penelitian dilakukan di laboratorium D-III Fisioterapi Universitas Abdurrab Pekanbaru, pada tanggal Waktu penelitian dilaksanakan dari 01 Februari sampai 01 Mei 2019.

\subsection{Teknik Pengambilan Sampel}

Dalam penelitian ini teknik pengambilan sampel yang digunakan adalah teknik purposive sampling yaitu teknik sampling non random sampling dimana peneliti menentukan pengambilan sampel dengan cara menetapkan ciri-ciri khusus yang sesuai dengan tujuan penelitian sehingga diharapkan dapat menjawab permasalahan penelitian. Sampel yang terpilih menjadi subjek penelitian diberikan penjelasan mengenai tujuan penelitian, manfaat penelitian serta diberikan penjelasan mengenai program penelitian yang akan dilakukan. Sampel yang bersedia mengikuti program penelitian diminta mengisi informed consent.

\subsection{Prosedur Intervensi}

Langkah-langkah yang diambil dalam prosedur penelitian ini dibagi menjadi tiga bagian yaitu: prosedur administrasi, prosedur pemilihan sampel dan Tahap pelaksanaan penelitian.

1) Prosedur administrasi

Prosedur administrasi dilakukan disini menyangkut: (1) Persiapan surat informed consent persetujuan sampel mengikuti program penelitian dan memberikan informasi terkait pelaksanaan program penelitian, (2) Mempersiapkan blangko-blangko dan alat pengukuran yaitu skala ruis untuk untuk mengukur derajat keparahan inkontinensia. (3) Mengisi blangko-blangko penelitian untuk diisi identitas diri dan mengumpulkan kembali.

2) Prosedur Pemilihan Sampel

Prosedur pemilihan sampel yang memenuhi kriteria inklusi dan eksklusi dari jumlah populasi. Jumlah sampel yang telah didapatkan yaitu 3 orang yang diberikan intervensi senam kegel.

3) Tahap Pelaksanaan Penelitian

Tahap pelaksanaan penelitian menyangkut: (1) Menyiapkan form pengukuran. (2) Membuat jadwal pengambilan data. (3) Intervensi dilakukan selama 2 minggu dengan intensitas 3 kali seminggu pada setiap sampel. (4) Setelah mendapatkan treatment selanjutnya dilakukan evaluasi menggunakan skala ruis untuk mengukur derajat inkontinensia. 


\section{Hasil Percobaan}

\subsection{Hasil dan Pembahasan}

\section{a. Hasil}

Hasil penelitian pelaksanaan fisioterapi yang telah dilakukan selama 2 minggu didapatkan hasil pada masing-masing sampel penelitian;

1. Hasil penelitian pada sampel I setelah diberikan senam kegel didapat perubahan kondisi. Pada $T_{0}$ nilai skor 15 dan pada $T_{12}$ didapatkan skor 10 .

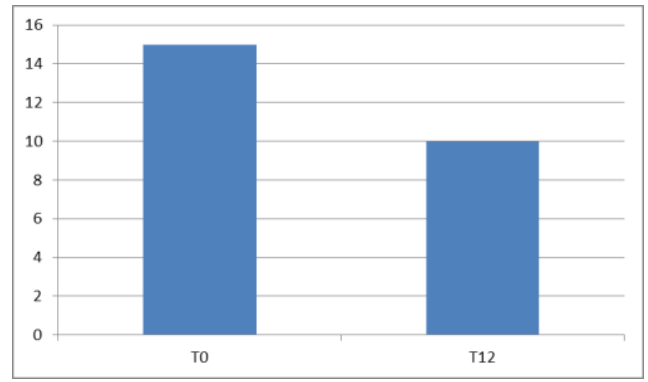

2. Hasil penelitian pada sampel II didapat perubahan perbaikan kondisi . Pada $\mathrm{T}_{0}$ nilai skor 13 dan pada $\mathrm{T}_{12}$ didapatkan skor 10 .

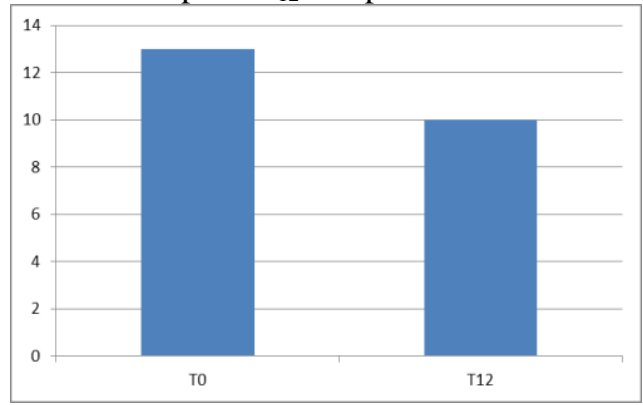

3. Hasil penelitian pada sampel III didapat perubahan perbaikan kondisi inkontinensi. Pada $\mathrm{T}_{0}$ nilai skor 15 dan pada $\mathrm{T}_{12}$ didapatkan skor 9.

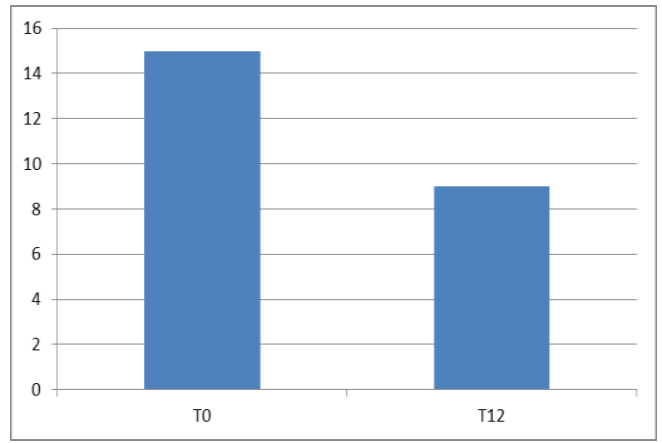

\section{b. Pembahasan}

Efek pemberian Aplikasi Senam Kegel untuk Menguatkan Otot Dasar Panggul.

Penelitian ini bertujuan untuk mengetahui terjadinya peningkatan kekuatan otot dasar panggul pada penderita inkontinensia, dlihat dari gambaran perubahan nilai skala paa skala ruis, dimana dideskriptifkannya perubahan dari inkontinensia berat kepada keadaan normal. Sampel penelitian berjumlah 3 orang yang memenuhi kriteria inklusi. Hasil analisis sebelum dan setelah diberikan intervensi sampel didapatkan perubahan peningkatan kekuatan otot dasar panggul dengan digambarkannya pada skala ruis. Nilai skala ruis pada sampel I didapatkan nilai 15 dengan kategori inkontinensia berat menjadi nilai 10 dengan kategori inkontinensia sedang. Pada sampel II, evaluasi di awal didapatkan nilai 13 dengan kategori inkontinensia berat, pada akhir evaluasi didapatkan 10 dengan kategori inkontinensia sedang. Sampel III pada evaluasi awal didapatkan 15, kategori inkontinensia berat dan diakhir evaluasi menjadi 9, kategori inkontinensia sedang. hal ini dapat disimpulkan bahwa terdapat peningkatan kekuatan otot dasar panggul dilihat dari penurunan derajat inkontinensia.

Senam kegel adalah latihan yang bertujuan untuk memperkuat sfingter kandung kemih dan otot dasar panggul, yaitu otot-otot yang berperan mengatur miksi dan gerakan yang mengencangkan, melemaskan kelompok otot panggul dan daerah genital, terutama otot pubococcygeal, sehingga seorang wanita dapat memperkuat otot-otot saluran kemih ${ }^{(11)}$.

Mekanisme kontraksi dan meningkatkan tonus otot polos dinding kandung kemih dapat terjadi karena adanya rangsang pada otot polos kandung kemih sebagai dampak dari latihan. Latihan ini dapat menimbulkan rangsangan sehingga meningkatkan aktivasi dari kimiawi, neuromuskuler dan muskuler. Otot polos kandung kemih mengandung filamen aktin dan miosin yang mempunyai sifat kimiawi dan saling berinteraksi. Proses interaksi diaktifkan oleh ion kalsium dan adenotriposfat (ATP) selanjutnya dipecah menjadi adenodifosfat (AD) untuk memberikan energi bagi konstraksi muskulus detrussor kandung kemih. Rangsangan melalui neuromuskuler akan meningkatkan rangsangan pada serat saraf otot polos kandung kemih terutama saraf parasimpatik yang merangsang produksi asetil cholin sehingga mengakibatkan terjadinya kontraksi. Mekanisme melalui muskulus, terutama otot polos kandung kemih akan meningkatkan metabolisme mitokondria untuk menghasilkan ATP yang dimanfaatkan oleh otot polos kandung kemih sebagai energi untuk kontraksi dan meningkatkan tonus otot polos kandung kemih. Frekwensi latihan sangat bergantung dari jenis latihan yang diberikan dan optimalisasi sangat ditentukan oleh benar atau tidaknya gerakan yang dilakukan. Latihan 
dilakukan sampai klien mencapai konrol berkemih $^{(12)}$.

Secara umum dengan bertambahnya usia maka kapasitas kandung kemih menurun, sisa urin dalam kandung kemih cenderung meningkat dan kontraksi otot kandung kemih yang tidak teratur semakin sering terjadi. Keadaan ini sering membuat lansia mengalami gangguan pemenuhan kebutuhan eliminasi urin yaitu Inkontinensia urin. Perubahan yang tercatat pada kandung kemih yang mengalami penuaan yaitu berkurangnya kapasitas kandung kemih, berkurangnya kemampuan kandung kemih dan uretra, berkurangnya tekanan penutupan uretra maksimal, meningkatnya volume urin sisa pasca berkemih, dan berubahnya ritme produksi urin di malam hari (13).

Secara teori inkontinensia urin lebih cenderung terjadi pada perempuan dengan jumlah paritas yang lebih sering. Hal ini sesuai dengan penelitian yang dilakukan oleh Moa (2017) tentang inkontinensia urin pada lanjut usia di posyandu lansia Desa Sumberdem kecamatan Wonosari Malang, penambahan berat dan tekanan selama hamil dapat menyebakan melemahnya otot dasar panggul karena ditekan selama sembilan bulan, besarnya peningkatan tekanan intra abdomen mampu untuk menekan urin ke uretra dengan sangat mudah. Proses persalinan yang lebih dari satu kali mengakibatkan timbulnya penguluran otot dasar panggul dan saraf pudendal sehingga timbulnya kelemahan pada otot dasar panggul dan tindakan-tindakan yang berkenaan dengan persalinan tersebut juga dapat membuat otototot dasar panggul rusak akibat regangan otot dan jaringan penunjang serta robekan jalan lahir. Untuk mengatasi permasalahan ini, penanganan yang tepat pada kasus inkontinensia urin pada lansia adalah dengan intervensi senam kegel dengan tujuan untuk meningkatkan kekuatan otot dasar panggul.

Pada penelitian ini di buktikan bahwa senam kegel dapat menguatkan otot dasar panggul pada lansia yang mengalami inkontinensia urin berdasarkan skala RUIS. Hal ini sesuai dengan penelitian yang dilakukan oleh Hartinah (2016) tentang pemberian senam kegel pada lansia di desa Undaan lor kecamatan Undaan kabupaten kundus adalah salah satu upaya untuk membangun kembali kekuatan otot dasar panggul yang memberikan efek menurunkan frekuensi inkontinensia urin dengan meningkatan kekuatan otot dasar panggul. Senam kegel memberikan pengaruh yang signifikan terhadap peningkatan kekuatan otot dasar panggul sehingga dianjurkan dilakukan untuk mencegah inkontinensia pada lansia dan keluhan terkait fungsi otot dasar panggul dan penelitian yang dilakukan oleh Sutarmi (2016) mengatakan bahwa senam kegel sangat bermanfaaat untuk menguatkan otot rangka pada dasar panggul, sehingga memperkuat fungsi sfingter eksterna pada kandung kemih.

\section{Kesimpulan}

Berdasarkan analisis penelitian yang telah dilakukan dan pembahasan dapat disimpulkan bahwa:

Senam Kegel dapat meningkatkan kekuatan otot dasar panggul pada kondisi inkontinensia urin. Kesimpulan ini didasari dari hasil evaluasi menggunakan Skala RUIS, dimana terdapat variasi dalam perbaikannya.

Hasil analisis sebelum dan setelah diberikan intervensi pada sampel didapatkan perubahan peningkatan kekuatan otot dasar panggul dengan digambarkannya pada skala ruis. Nilai skala ruis pada sampel I didapatkan nilai 15 dengan kategori inkontinensia berat menjadi nilai 10 dengan kategori inkontinensia sedang. Pada sampel II, evaluasi di awal didapatkan nilai 13 dengan kategori inkontinensia berat, pada akhir evaluasi didapatkan 10 dengan kategori inkontinensia sedang. Sampel III pada evaluasi awal didapatkan 15, kategori inkontinensia berat dan diakhir evaluasi menjadi 9, kategori inkontinensia sedang. hal ini dapat disimpulkan bahwa terdapat peningkatan kekuatan otot dasar panggul dilihat dari penurunan derajat inkontinensia.

\section{REFERENSI}

[1]. Muhith, Adan Sandu, S. 2016. Pendidikan Keperawatan Gerontik, CV Andi Offset : Yogyakarta

[2]. Maryam, S.R. Mia Fatma Ekasari.Rosidawati. Ahmad Jubaedi, Irwan Batubara. 2008. Mengenal Usia Lanjut Perawatannya, Salemba Medika : Jakarta

[3]. Darmojo, B. 2015. Geriatri (Ilmu Kesehatan Usia Lanjut), Fkui : Jakarta

[4]. Purnomo, B. B. 2011. Dasar-dasar Urologi, CV Sagung Seto : Jakarta

[5]. Moa, H.M, Susi Milwati, Sulasmini. 2017. Pengaruh Bladder Training Terhadap 
Inkontinensia Urin Pada Lanjut Usia Di

Posyandu Lansia Desa Sumberdem

Kecamatan Wonosari Malang. Nursing News Volume 2, Nomor 2.

[6]. Darmojo, B. 2015. Geriatri (Ilmu Kesehatan Usia Lanjut), Fkui : Jakarta

[7]. Pribakti, B, D.R.Spog (K). 2011. Dasar-dasar Urokinekologi, CV Sagung Seto : Jakarta

[8]. Widianti, A. T Dan Atikah Proverawati. 2018. Senam Kesehatan, Nuha Medika : Yogyakarta

[9,11]. Novera, M. 2016 Pengaruh Senam Kegel Terhadap Frekuensi BAK Pada Lansia Dengan Inkontinensia Urin. Issn: 19799292. E-issn: 2460-5611

[10, 12]. Sulistyaningsih, D.R. 2015. Latihan Otot Dasar Panggul Efektif Untuk Mengatasi Inkontinensia Urin Pada Klien Post Operasi Prostatectomy. Jurnal Keperawatan Dan Pemikiran Ilmiah. Issn 2476-8987

[13]. Pamungkas, M.R, Nurhayati, Musiana. 2013. Pengaruh Latihan Kandung Kemih (Blandder Training) Terhadap Interval Berkemih Wanita Lanjut Usia (Lansia) dengan Inkontinensia Urin. Jurnal keperawatan, volume IX, No. 2. 